\title{
PERFORMANCE OF DEVELOPED SURFACE IRRIGATION SYSTEM IN ASSUIT
}

\author{
El-Nakib A. A. ${ }^{1}$, El-Mesery A. A. ${ }^{2}$, El-Lathy A. M. ${ }^{3}$, \\ Hassan S. S. ${ }^{4}$ and El-Attar M. H. ${ }^{5}$
}

\begin{abstract}
This study was conducted at the On-farm Irrigation Development Project in Assuit Governorate, Upper Egypt. The objectives of this work were to study the performance of the developed surface irrigation system and comparing it with the traditional surface irrigation system. The performance indicators were land losses, conveyance efficiency, irrigation time, application efficiency, filed water use efficiency and crop yield. Where the most important results could be summarized as follows: a) The saved agricultural land through using buried pipes as developed Mesqa about $2.34 \%$ and in the lining canal it $1.51 \%$ compared with traditional earth Mesqa which were occupied by the channels. $b$ ) Average conveyance efficiencies were as $81.41 \%, 92.52 \%$, and $98.61 \%$ for earthen Mesqa, lining Mesqa and buried pipes respectively. c) Average application efficiencies were as $58.82 \%, 79.07 \%$ and $82.09 \%$ for earthen Mesqa, lining Mesqa and buried pipes respectively. d) Irrigation time decreased $32.75 \%$ by using buried pipes Mesqa and $20.91 \%$ by using lining Mesqa compared with earthen Mesqa. e) The productivity of wheat and maize increased 18.75 and $21.4 \%$ under buried pipe respectively. Also, wheat and maize was $9.38 \%$ and $10.7 \%$ respectively under lining Mesqa compared with earthen Mesqa.f) The values of field water use efficiency (FWUE) for wheat were $3.23 \mathrm{~kg} / \mathrm{m}^{3}, 1.72 \mathrm{~kg} / \mathrm{m}^{3}$ and $1.49 \mathrm{~kg} / \mathrm{m}^{3}$ under buried pipe, lining Mesqa and traditional surface irrigation respectively. and, $2.65 \mathrm{~kg} / \mathrm{m}^{3}, 1.38 \mathrm{~kg} / \mathrm{m}^{3}$ and $1.21 \mathrm{~kg} / \mathrm{m}^{3}$ under buried pipe, lining Mesqa and traditional surface irrigation respectively.
\end{abstract}

1. Prof. Emeritus of Agric. Eng., Fac of Agric. Eng., Al-Azhar Univ, Cairo.

2. Prof. of Agric. Eng., Fac of Agric. Eng., Al-Azhar Univ, Cairo.

3. Prof. of Agric. Eng., Fac of Ag. Eng., Al-Azhar Univ, Assiut.

4. Prof. of Agric. Eng. Rese. Inst. Agric. Res. Cen., MOA, Cairo, Egypt.

5. Demonstrator of Agric. Eng., Fac of Agric. Eng., AL-Azhar Univ, Assiut. 


\section{INTRODUCTION}

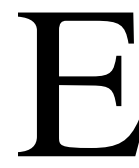

gyptian irrigation system is considered one of the most complicated systems in the world. Water in the River Nile is diverted to agricultural lands through a hierarchy of public canals that comprise carrier, or principal canals, main canals, branch canals and sub-branch canals. The branch canals deliver water into smaller tertiary channels (Mesqas) and water is conveyed from the Mesqas, or in some cases directly from canals, to the fields by farm ditches or (Marwas).(IFAD, 2012)

The surface irrigation is way of irrigation water distribution under gravity flow over the soil surface. Therefore, soil acts as the growing media in which water is stored and the conveyance medium over which water flows as it spreads and infiltrates. (Walker,1989)

Surface irrigation is a method of irrigation in which water is applied to the land by allowing it to flow by simple gravity, before infiltrating. It includes various systems depending upon the relative magnitude of the surface flooding phase and infiltration phase after accumulation (submersion). (Phocaides A, 2007)

Surface irrigation is the oldest and most common method of applying water to croplands. Also, referred to as flood irrigation, the essential feature of this irrigation system is that water is applied at a specific location and allowed to flow freely over the field surface, and thereby apply and distribute the necessary water to refill the crop root zone (USDA, 2012)

The features of the national project on-farm irrigation development project in the old lands (OFIDO) is improving the Mesqa delivery system this is accomplished by changing irrigation delivery system from earthen Mesqa with multiple lifting point to low pressure buried PVC pipelines with single lifting (pumping) point at the head of the Mesqa.As well as improving on farm conveyance system by changing from earthen Marwa to low pressure buried PVC pipelines and irrigate the field by using alfalfa valve. Establishment of field water users associations (FWUA) for each individual Mesqa.(El-Gendy, 2011). 
The surface irrigation is most widely used over the world because of its simplicity and low capital costs. Furrow irrigation is one of the oldest methods of surface irrigation. (Mostafa et al, 2010)

The conventional ditch water loss test shows the water loss from the 90 $\mathrm{m}$ study section for a 200 minute test period was $21.21 \mathrm{~m}^{3}$ or $(1.18$ $\mathrm{L} / \mathrm{min} / \mathrm{m}$ ). Most of this loss apparently occurred through deep percolation and canal leakage. The water conveyance efficiency for conventional ditch is $68.6 \%$. (Jibin and Foroud, 1997)

The application efficiency is the most important in terms of design and management since it reflects the overall beneficial use of irrigation water. It is the ratio of the average depth of irrigation water infiltrated and stored in the plant root zone to the average depth of irrigation water applied, expressed as a percentage. (FAO, 1989)

The use of perforated tubes is claimed to be one of the ways to improve the efficiency of surface irrigation methods (borders and furrows). The perforated pipe system is a simplified type of gated pipe system. It is mainly constructed of a portable line, which could be handled in the field. The pipeline usually has uniformly spaced outlet and usually of aluminum or PVC pipe. (Hassan, 1998)

The water is the most valuable asset of irrigated agriculture. Controlled surface irrigation systems by using enclosed pipelines have been successfully demonstrated in recent years. The perforated pipe technique is a simplified type of gated pipe. (Abd El-Motaleb et. al, 2006)

This research aims to evaluate the applications of the national project (OFIDO) for developed surface irrigation and increase the water use efficiency and minimizing water losses and raise the efficiency of surface irrigation system.

\section{MATERIALS AND METHODS}

\section{$\underline{2.1}$ Experimental site}

A field experiment was carrid out during growing two successive seasons of winter 2015/2016 and summer 2016 in Upper Egypt at Assuit governorate - El-fath city at Arab El-atawlah branch canal $\left(27^{\circ} 15^{\prime} / \mathrm{N}\right.$, $\left.31^{\circ} 13^{\prime} / \mathrm{E}\right)$ in the On-Farm Irrigation development in the old lands (OFIDO). Fig (1). Shows the general of developed surface irrigation. 
The study was conducted to evaluate the developed surface irrigation system and their effects on field water use efficiency.

To evaluate the impact of developed surface irrigation in the old lands areas of 47 feddan from fields that has been irrigated by developed surface irrigation through (OFIDO) national project under supervisor Ministries of Agriculture and Irrigation at Assuit governorate were selected. In this area, land losses were determined through measuring the area of traditional Mesqa and Maraw.

Three areas were irrigated by three systems. The Firest area was $125 \times 18.5 \mathrm{~m}$ which irrigated by bured pipe $180 \mathrm{~mm}$ diameter, The Second area $115 \times 12 \mathrm{~m}$ was irrigated by lining mesqa, $0.6 \mathrm{~m}$ width and $0.6 \mathrm{~m}$ height, The Thired area $110 \times 13.2 \mathrm{~m}$ irrigated by traditional mesqa.

To compare the developed surface irrigation system with non developed surface irrigation. In this areas land losses were obtained from measuring the area of traditional Mesqa and Maraw. As well as this field Conveyance efficiency, Application efficiency, productivity, irrigation time and field water use efficiency.

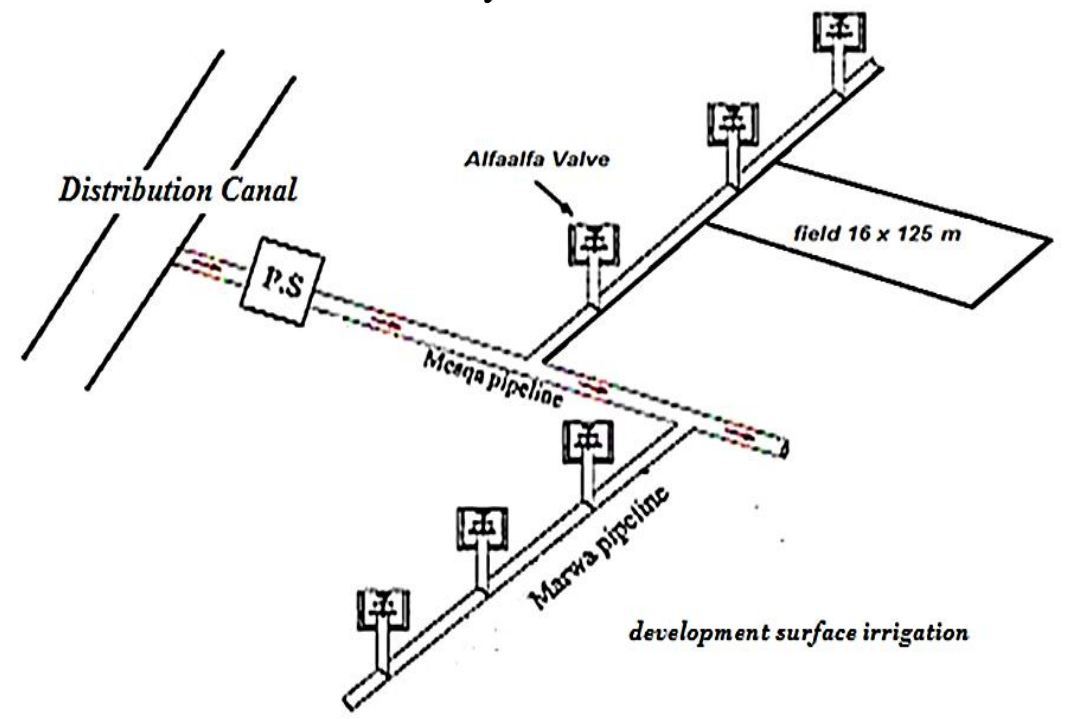

Fig. (1): Shows the general of developed surface irrigation

\subsection{Soil properties:}

The soil texture of the experimental site according to (Black, G. R. and K. Hartage, 1986) is classified as clay soil as shown in table (1), (2) and (3). 
Table (1): The physical and mechanical analysis of the soil, at first experimental field (traditional surface irrigation)

\begin{tabular}{|c|c|c|c|c|c|c|c|c|}
\hline \multirow{3}{*}{$\begin{array}{l}\text { Depth } \\
\text { cm }\end{array}$} & \multicolumn{4}{|c|}{ Mechanical analysis } & \multirow{3}{*}{$\begin{array}{l}\text { Soil } \\
\text { exture }\end{array}$} & \multirow{3}{*}{$\begin{array}{c}\text { Field } \\
\text { capacity } \\
\%\end{array}$} & \multirow{3}{*}{$\begin{array}{c}\text { Wilting } \\
\text { point } \\
\%\end{array}$} & \multirow{3}{*}{$\begin{array}{c}\text { Bulk } \\
\text { density } \\
\text { g/cm }\end{array}$} \\
\hline & \multirow[b]{2}{*}{ clay } & \multirow[b]{2}{*}{ silt } & \multicolumn{2}{|c|}{ sand } & & & & \\
\hline & & & F.S & C.S & & & & \\
\hline 0 - 15 & 54.52 & 22.77 & 15.2 & 7.51 & \multirow{4}{*}{ Clay } & 35.3 & 18.1 & 1.18 \\
\hline $15-30$ & 57.15 & 20.32 & 16.3 & 6.23 & & 37.2 & 19.2 & 1.1 \\
\hline $30-45$ & 56.85 & 22.88 & 15.11 & 5.16 & & 35.6 & 21.1 & 1.20 \\
\hline $45-60$ & 58.49 & 23.1 & 14.21 & 4.2 & & 34.9 & 22.0 & 1.22 \\
\hline
\end{tabular}

Table (2): The physical and mechanical analysis of the soil, at second experimental field (developed surface irrigation Pipe line).

\begin{tabular}{|c|c|c|c|c|c|c|c|c|}
\hline \multirow{3}{*}{$\begin{array}{c}\text { Depth } \\
\text { cm }\end{array}$} & \multicolumn{4}{|c|}{ Mechanical analysis } & \multirow{3}{*}{$\begin{array}{l}\text { Soil } \\
\text { texture }\end{array}$} & \multirow{3}{*}{$\begin{array}{c}\text { Field } \\
\text { capacity } \\
\%\end{array}$} & \multirow{3}{*}{$\begin{array}{c}\text { Wilting } \\
\text { point } \\
\%\end{array}$} & \multirow{3}{*}{$\begin{array}{c}\text { Bulk } \\
\text { density } \\
\text { g/cm }\end{array}$} \\
\hline & \multirow[b]{2}{*}{ clay } & \multirow[b]{2}{*}{ silt } & \multicolumn{2}{|c|}{ sand } & & & & \\
\hline & & & F.S & C.S & & & & \\
\hline $0-15$ & 55.62 & 19.08 & 17.2 & 8.1 & \multirow{4}{*}{ Clay } & 36.2 & 17.4 & 1.12 \\
\hline $15-30$ & 56.1 & 23.0 & 15.1 & 5.8 & & 38.1 & 18.1 & 1.13 \\
\hline $30-45$ & 57.85 & 19.4 & 15.89 & 6.86 & & 36.5 & 20.2 & 1.15 \\
\hline $45-60$ & 59.25 & 21.35 & 13.9 & 5.5 & & 35.8 & 19.0 & 1.17 \\
\hline
\end{tabular}

Table (3): The physical and mechanical analysis of the soil, at third experimental field (developed surface irrigation lining Mesqa)

\begin{tabular}{|c|c|c|c|c|c|c|c|c|}
\hline \multirow{3}{*}{$\begin{array}{c}\text { Depth } \\
\text { cm } \\
\end{array}$} & \multicolumn{4}{|c|}{ Mechanical analysis } & \multirow{3}{*}{$\begin{array}{c}\text { Soil } \\
\text { texture }\end{array}$} & \multirow{3}{*}{$\begin{array}{c}\text { Field } \\
\text { capacity } \\
\%\end{array}$} & \multirow{3}{*}{$\begin{array}{c}\text { Wilting } \\
\text { point } \\
\%\end{array}$} & \multirow{3}{*}{$\begin{array}{c}\text { Bulk } \\
\text { density } \\
\text { g/cm }\end{array}$} \\
\hline & \multirow[b]{2}{*}{ clay } & \multirow[b]{2}{*}{ silt } & \multicolumn{2}{|c|}{ sand } & & & & \\
\hline & & & F.S & C.S & & & & \\
\hline $0-15$ & 54.98 & 22.45 & 16.1 & 7.45 & \multirow{4}{*}{ Clay } & 37.1 & 17.9 & 1.14 \\
\hline $15-30$ & 55.12 & 22.89 & 15.65 & 6.34 & & 36.5 & 18.5 & 1.15 \\
\hline $30-45$ & 56.59 & 20.95 & 16.55 & 5.91 & & 36.9 & 19.8 & 1.18 \\
\hline $45-60$ & 59.87 & 21.12 & 14.20 & 4.81 & & 35.2 & 20.0 & 1.19 \\
\hline
\end{tabular}

\subsection{Field Crops in the study}

developed and traditional surface irrigation were evaluated on farmer's fields. Three fields were selected for two crops wheat (Seds12) in winter season and maize (Giza 15) in summer season where, wheat and maize are considering principle crops in the study area.

\subsection{Description of developd surface irrigation.}

\subsubsection{UPVC pipelines:}

In developed surface irrigation under (OFIDO) project the field received irrigation water from the branch canal through electric pumping unit to the main and branch buried UPVC pipes instead of traditional Mesqa and 
Marwa. The main line (Mesqa) diameter ranged from $225 \mathrm{~mm}$ to $280 \mathrm{~mm}$ and branch line (Marwa) diameter was $180 \mathrm{~mm}$. The UPVC pipes were connected together using faucet rubber ring jointing system. On branch line there is risers ended by $160 \mathrm{~mm}$ alfaalfa valve. Fig (2). Shows general layout for buried pipelines Mesqa ( lateral canal ).

\subsubsection{Lining Mesqa (U-Section ):}

In the present work, one U-section Mesqas were used. It is about lifted Mesqas up to the ground. Mesqas aspects and its base of bricks U-section height $60 \mathrm{~cm}$ and width $60 \mathrm{~cm}$. The water is lifted to the Mesqas using pumps.The irrigation water come through holes located at the head of each Marwa. Fig (3). Shows general layout for lining Mesqa ( lateral canal ).

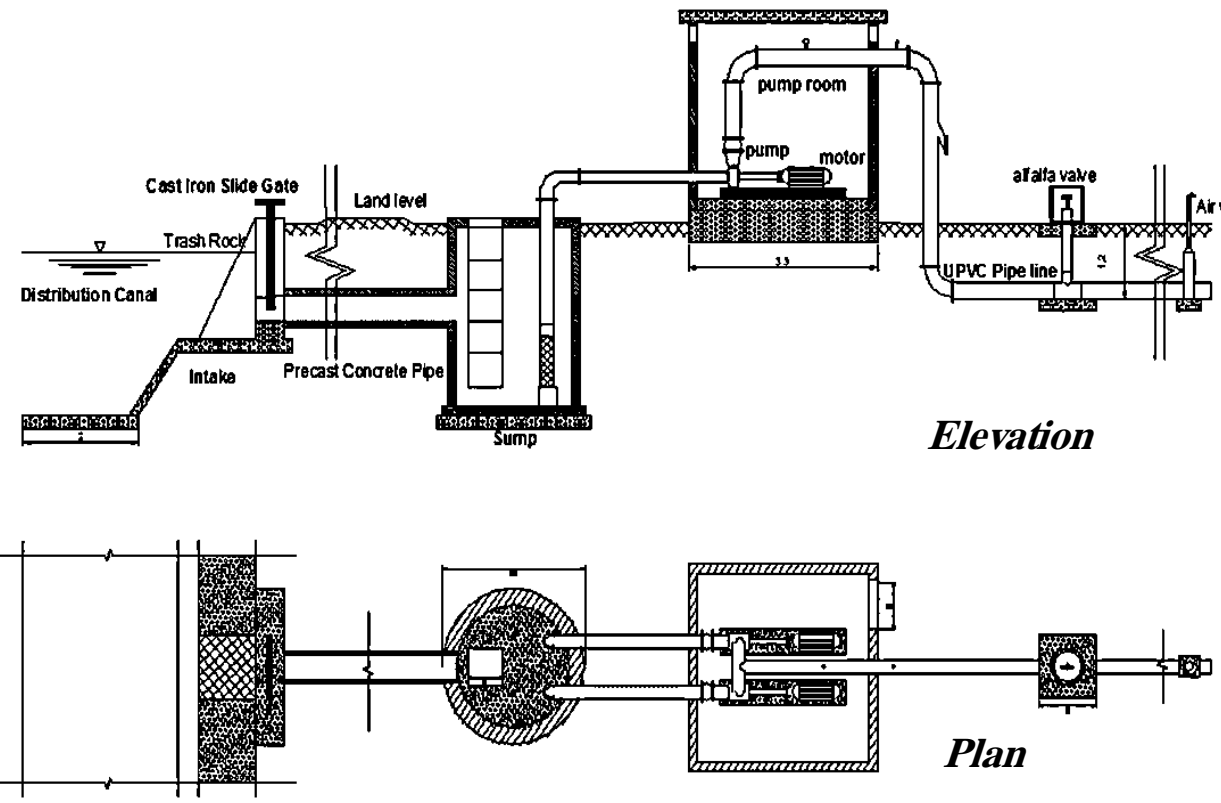

Fig (2): Shows general layout for buried pipelines Mesqa (lateral canal).

\subsubsection{Traditional surface irrigation:}

In traditional surface irrigation the tertiary canals earthen Mesqas receive irrigation water by individual farmer's pumping units and traditional surface irrigation. The pump lift irrigation water from the branch canal to convey irrigation water to earthen Marwa by gravity then to the field. The area served by a Mesqa is usually 20 to 100 feddan. 


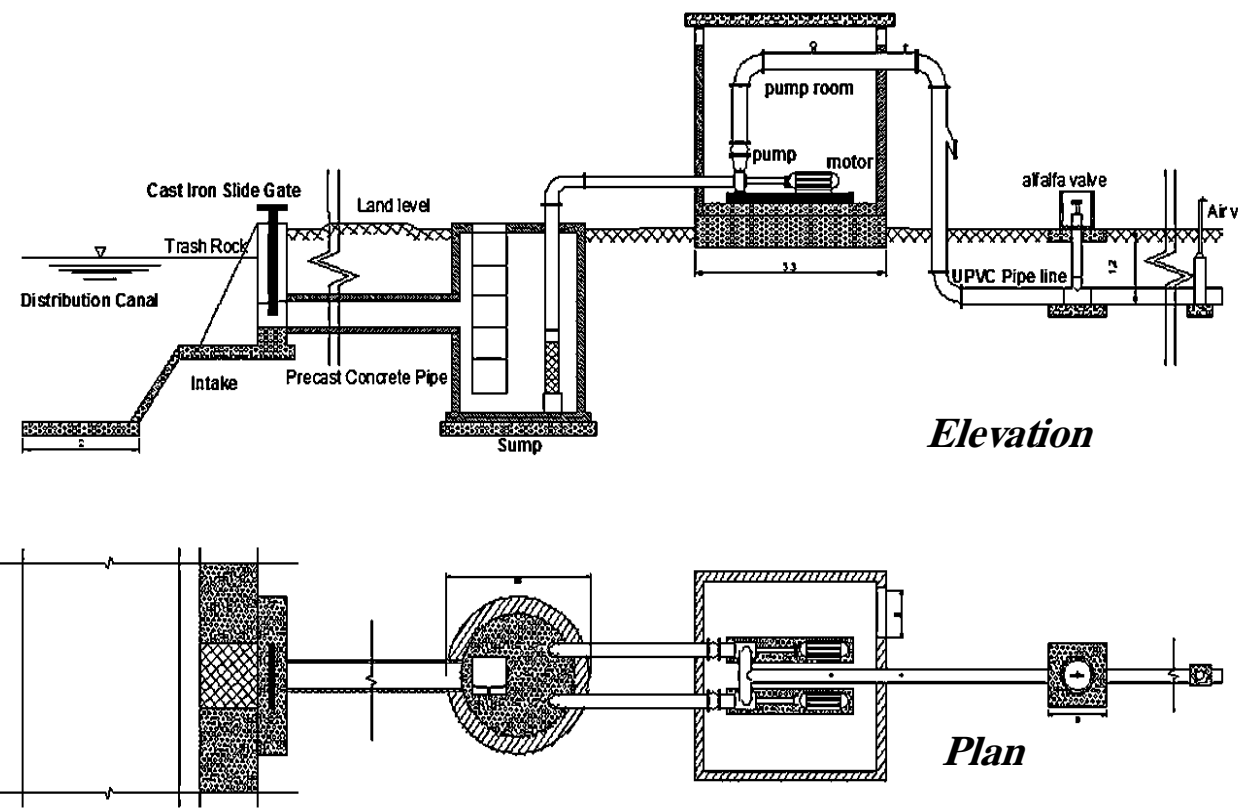

Fig (3): Shows general layout for lining Mesqa ( lateral canal ).

\subsection{Land losses through traditional irrigated area}

To calculate land losses area for earthen Mesqa, earthen Marwa, lining Mesqa and lining Marwa three different zones were surveyed. The total area of the zone was determined. area 47 feddan were chosen to determine land losses ratio in earthen Mesqa and lining Mesqa.To calculate the ratio between Mesqa area and the total area equation (1) and (2) was used.

$$
\mathbf{A}_{\mathbf{m}}=\mathbf{W}_{\mathbf{v}} * \mathbf{L}
$$

Where:
$\mathbf{A}_{\mathbf{m}}=$ area of Mesqa, $\mathrm{m}^{2}$
$\mathbf{L}=$ length of Mesqa, $\mathrm{m}$.
$\mathbf{W}_{\mathbf{v}}=$ average width of Mesqa, $\mathrm{m}$.

$$
\mathrm{R}=\frac{A_{m}}{A} \times 100
$$

Where:

$\mathbf{R}=$ the ratio between Mesqa area and the total area, $\%$.

$\mathbf{A}=$ total area of zone, $\mathrm{m}^{2}$. 


\subsection{Conveyance efficiency (Ec).}

The conveyance efficiency was measured in earthen canal by measuring discharges from pump by using a tank of known size in known time and measuring the discharge at the entrance of the fields by using pipe and tank of. The conveyance efficiency was obtanied by the equation (3) according to (Howell, 2003). This test was replicated six times in summer and six times in winter.

$$
\mathbf{E}_{\mathrm{c}}=\frac{W_{f}}{W_{d}} \times 100
$$

Where:

$\mathbf{E}_{\mathbf{c}}=$ Conveyance efficiency, $\%$.

$\boldsymbol{W}_{\boldsymbol{f}}=$ Water delivered to the irrigation plot, $\mathrm{m}^{3}$.

$\boldsymbol{W}_{\boldsymbol{d}}=$ Water delivered from the source, $\mathrm{m}^{3}$

\subsection{Application efficiency (Ea).}

Water application efficiency was calculated from the following formula (4) according to (FAO, 1989)

$$
\mathrm{Ea}=[\mathrm{WDZ} / \mathrm{WT}]^{* 100}
$$

Where:

$\mathbf{W D Z}=$ Depth of water stored in the root zone, $\mathrm{cm}$.

$\mathbf{W T}=$ Gross depth of applied water, $\mathrm{cm}$.

Soil moisture distribution "SMD" was determined according to Liven and Van Rooyen (1979). For each treatment, six locations were taken along the field. The soil moisture content was determined using the gravimetric method. SMD was identified at six points along field and three depths at root zone (0-20, 20-40 and 40-60) before and after irrigation. Soil samples were collected by soil auger. Moisture content for each treatment was measured directly before irrigation and 48 hours after irrigation. Soil moisture content percentage (S.M.C.) \% was determined as a dry weight according to the following equation (5):

$$
\text { S.M.C }=\left(\mathbf{W}_{1}-\mathrm{W}_{2}\right) / \mathrm{W}_{2} * 100 .
$$

Where:

$\mathbf{W}_{\mathbf{1}}=$ weight of the wet soil sample, $\mathrm{g}$. 
$\mathbf{W}_{\mathbf{2}}=$ weight of the oven dried soil samplem, g. at $105{ }^{0} \mathrm{C}$ for 24 hours.

Equation (6) was used to find the depth of water that entered to root zone $\left(\mathbf{W}_{\text {DZ }}\right)$ during irrigation.

$$
W . D . Z=[(S . M . W 2-S . M . W 1) * \rho * D / 100 \ldots .(6)
$$

Where:

$\mathbf{P}=$ specific weight of soil

S.M.W2 = soil moisture content in the Field 48 hours after irrigation, $\%$.

S.M.W1 $=$ is moisture content in the field before irrigation, $\%$.

$\mathbf{D}=$ root depth, $\mathrm{cm}$.

\subsection{Field Water use efficiency (FWUE).}

After determining the amount of water applied to crop in the season. Water use efficiency was calculated according to the following equation (7) according to (Howell, 2003).

$$
\text { FWUE }\left(\mathrm{kg} / \mathrm{m}^{3}\right)=\frac{\text { Yield, },\left(\frac{\mathrm{kg}}{\mathrm{fed}}\right)}{\text { water applied },\left(\frac{\mathrm{m}^{3}}{\mathrm{fed}}\right)} \times 100
$$

\section{RESULTS AND DISCUSSION}

\subsection{Effect of buried pipes and lining canal as developed conveyance}

\section{systems on decreasing land losses in irrigated fields.}

Mesqa and Marwa are the last connection in conveyance irrigation water system in the Egyptian fields. Where irrigation water is transfers from branch canal to Mesqa then to Marwa and from Marwa to the field. Traditional Mesqas and Marwas network occupying space of agricultural land area and uses the Buried Pipes network instead of traditional Mesqas and Marwas led to increase agricultural area and the results as shown in Table (2) indicated that the area added to buried pipes was $4233.6 \mathrm{~m}^{2}$ which represent $2.34 \%$ increasing in the cultivated area.

Using the lining canal instead of traditional mesqs and Marwas led to increase agricultural area. The results shown in Table (4) indicated that the area added to lining canal was $2977.8 \mathrm{~m}^{2}$ with percentage of $1.51 \%$ added area. The average percentage of increase in the studied developed irrigation areas using lining Mesqas was $1.2 \%$. Fig (4) shows the effect of buried pipes and lining Mesqas and Marwas on increase the agriculture area. 
Table (4) Effect of developed Mesqas and Marwas on the add agriculture area:

\begin{tabular}{|c|c|c|c|}
\hline $\begin{array}{c}\text { Area } \\
\text { (feddan) }\end{array}$ & $\begin{array}{c}\text { Type of } \\
\text { improvement }\end{array}$ & $\begin{array}{c}\text { Added area } \\
\left(\mathrm{m}^{2}\right)\end{array}$ & $\begin{array}{c}\text { The percentage } \\
\text { of add area }\end{array}$ \\
\hline 47 & Buried pipes & 4233.6 & $2.342 \%$ \\
\hline 47 & Lining canal & 2977.8 & $1.508 \%$ \\
\hline
\end{tabular}

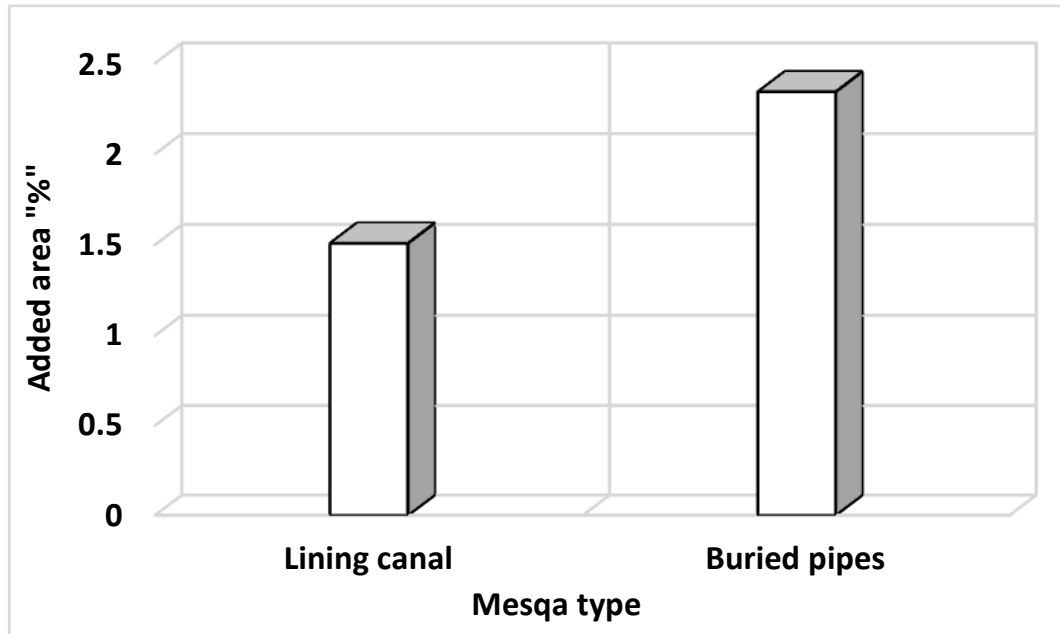

Fig.(4): Effect of lining Mesqas and buried pipes and Marwas on the added agriculture area.

\subsection{Effect of using buried pipes, lining Mesqa and lining Marwa instead of earthen Mesqa and Marwa on conveyance efficiency.}

Water conveyance loss consists mainly of evaporation and seepage into the soil from the sloping surfaces and bed of the canal. The conveyance efficiency (Ec) mainly depends on the length of the canals, the soil type or permeability of the canal banks and the condition of the canals. The conveyance efficiency $(\mathrm{Ec})$ of earthen Mesqa in summer season, it was $80.35 \%$ for $530 \mathrm{~m}$ length of Mesqa and in winter season it was $82.46 \%$. In lining Mesqa the conveyance efficiency $(\mathrm{Ec})$ in summer season was $91.84 \%$ for 510 m length of Mesqa and in winter season was $93.20 \%$. For buried pipes the conveyance efficiency $(\mathrm{Ec})$ in summer season was $98.34 \%$ for 655 m length of pipe and in winter season was $98.78 \%$. The 
conveyance losses in earthen Mesqa ranged from $19.65 \%$ to $17.54 \%$ because of evaporation and seepage into the soil from the surfaces of the sloping side sand bed of the canal. In lining canal there isn't seepage so, the conveyance losses is less than earthen Mesqa it ranged from $8.16 \%$ to $6.80 \%$. The conveyance losses in buried pipes were $1.66 \%$ and 1.22 $\%$ because of small evaporation from alfalfa valve or small seepage from pipes. The conveyance efficiency (Ec) was shown in Fig. (5)

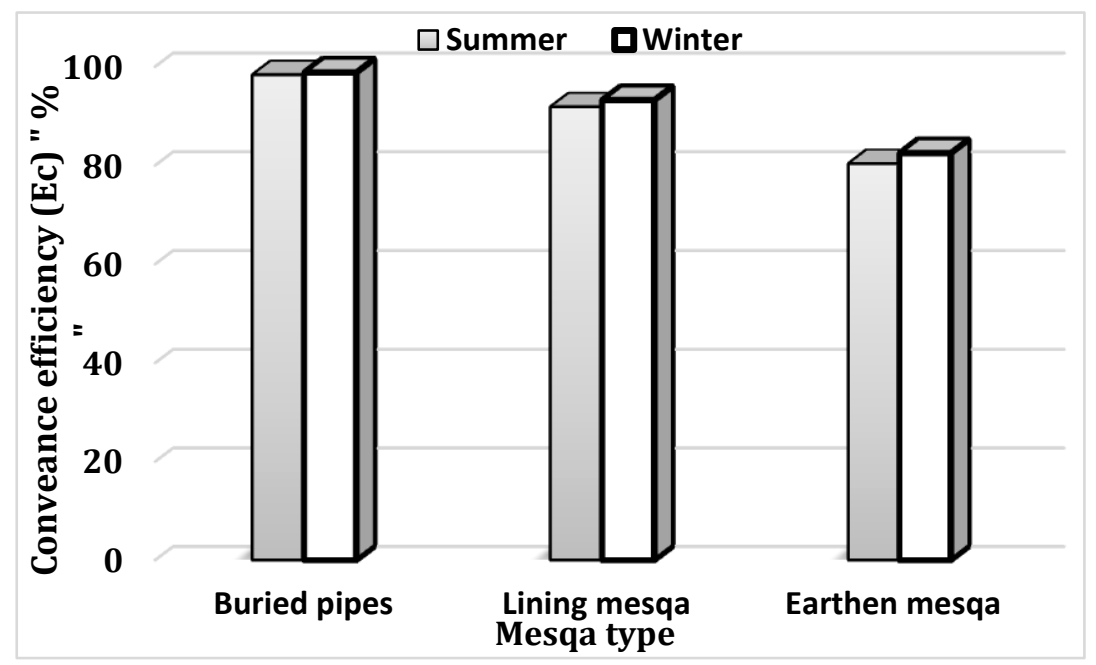

Fig.(5): Effect of using buried pipes, lining Mesqa and earthen Mesqa on conveyance efficiency, $(\mathrm{Ec})$

\subsection{Application efficiency (Ea)}

Water application efficiency (Ea) is a general indicator of the irrigation system performance. Irrigation application efficiency (Ea) affected by the type of surface irrigation system developed or traditional, where application efficiency increased by decreasing the irrigation water applied. Water application efficiency (Ea) was calculated for the different irrigations and the values are shown in Fig. (6) and (7). Irrigation application efficiencies were $81.71,82.59,81.13,86.59$, 77.88 and $84.71 \%$ with an average of $82.44 \%$ during the winter season under Buried pipes Mesqa and were 79.46 , 84.99 , 80.72, 84.75 , 79.32 , and $81.27 \%$ in the summer seasons with an average of $78.67 \%$. 


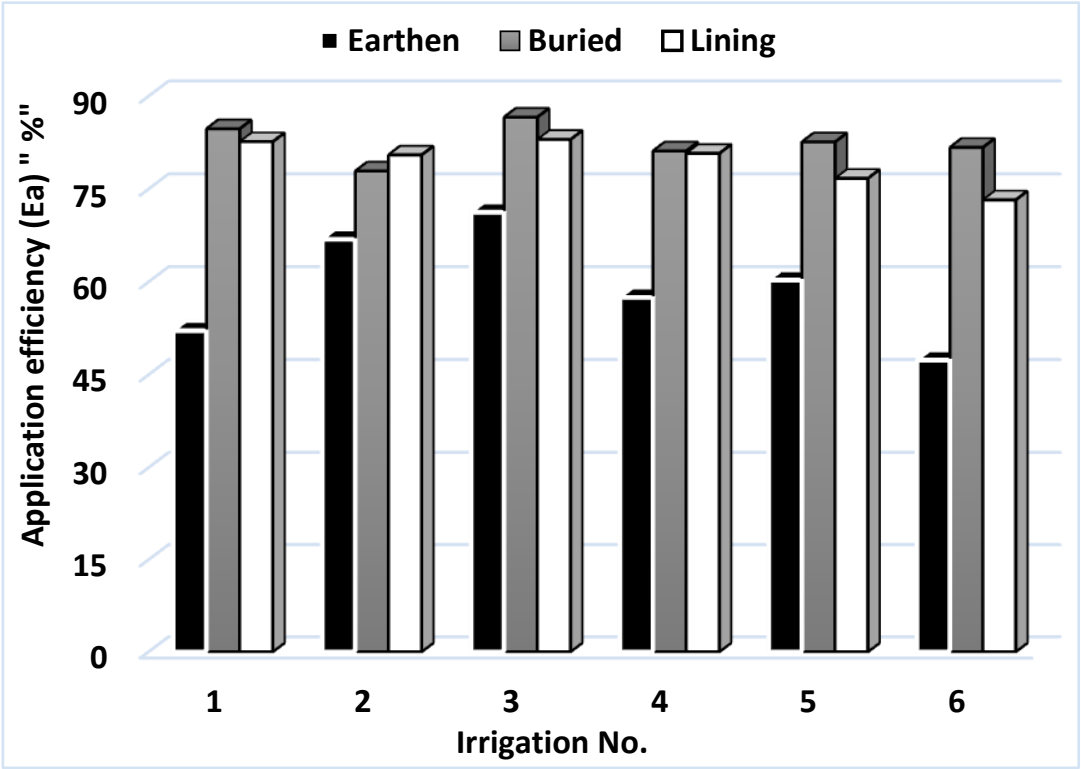

Fig.(6): Application efficiency during winter season.

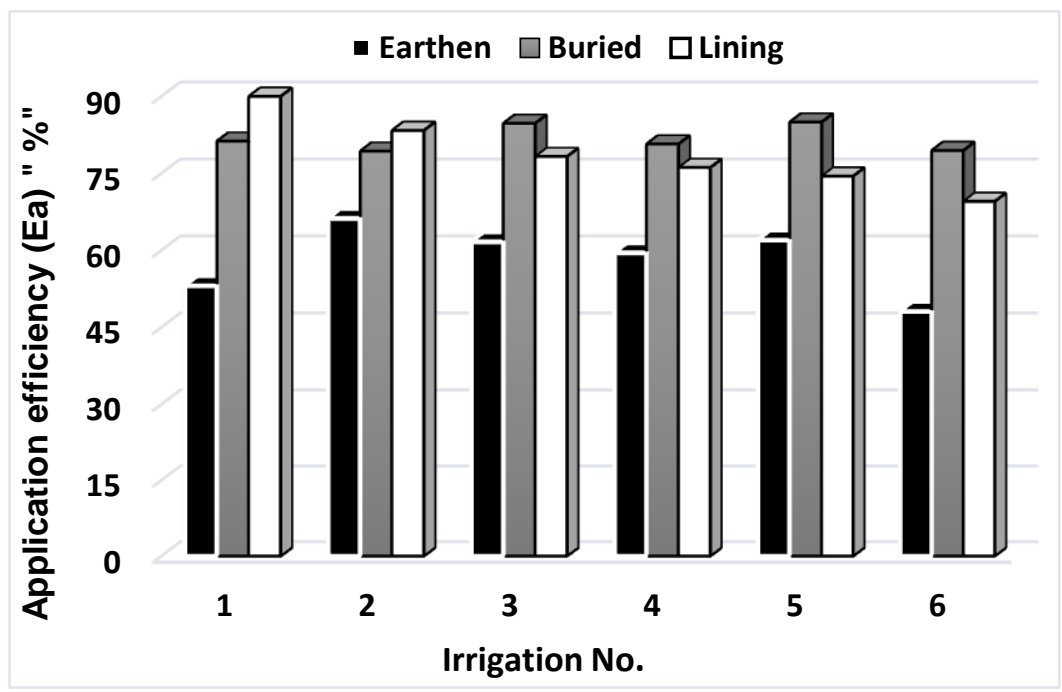

Fig.(7): Application efficiency during summer season.

Also, Irrigation application efficiencies were 73.22, 76.71, 80.74, 82.99, 80.49 and $82.62 \%$ with an average of $79.46 \%$ during the winter season under Lining Mesqa and were 69.54 , 74.46 , 76.14 , 78.28 , 83.36 , and $90.23 \%$ in the summer seasons with an average of $78.67 \%$. Under traditional surface irrigation ( Earthen Mesqa ) the application efficiency 
was $47.35,60.27,57.47,71.22,66.86$ and $52.08 \%$ with an average of $59.21 \%$ during the winter season. In the summer season the application efficiencies were $48.08,61.99,59.51,61.64,66.21$ and $53.08 \%$ with an average of $58.42 \%$. The results show that irrigation application efficiency under Buried pipes Mesqa was higher by $23.23 \%$ during the winter season and $20.25 \%$ during the summer season as compared to Earthen Mesqa. Also, under Lining Mesqa was higher by $23.33 \%$ during the winter season and $20.25 \%$ during the summer season as compared to Earthen Mesqa where large amount of water is applied. So, developed surface irrigation saved a considerable volume of water.

\subsection{Irrigation time.}

One of the benefits of developed surface irrigation and converting traditional Mesqa and Marwa to buried pipes is facilitate the irrigation operation and reduce the necessary time to irrigate one feddan. Fig.(8) show results of irrigation time in two consecutive seasons under buried pipes, lining Mesqa and earthen Mesqa. In winter season under buried pipes the irrigation time per feddan was was 101, 95, 93, 97, 95 and 91minute with an average of 95 minute. Also, lining Mesqa the irrigation time per feddan was 120, 117, 114, 107, 107 and 101 minute with an average of 111 minute and in traditional surface irrigation it was $149,144,141,141,138$ and 135 minute with an average of 141 minute. In summer season under buried pipes the irrigation time per feddan was 103, 96, 95, 101, 97 and 93 minute with an average of 98 minute. Also, lining Mesqa the irrigation time per feddan was 123, 120, 117, 117, 114 and 107 minute with an average of 116 minute and in traditional surface irrigation it was $155,147,141,149,138$, and 144 minute with an average of 146 minute. The results show that irrigation time under buried pipes was less by 46 min during winter season and 48 min during summer season as compared to traditional surface irrigation. Also, under Lining Mesqa was less by $30 \mathrm{~min}$ during the winter season and $30 \mathrm{~min}$ during the summer season as compared to Earthen Mesqa The differences in irrigation time between developed and traditional surface 
irrigation are because of the speed transfer water in burid Mesqa and lining Mesqa about earthen Mesqa .
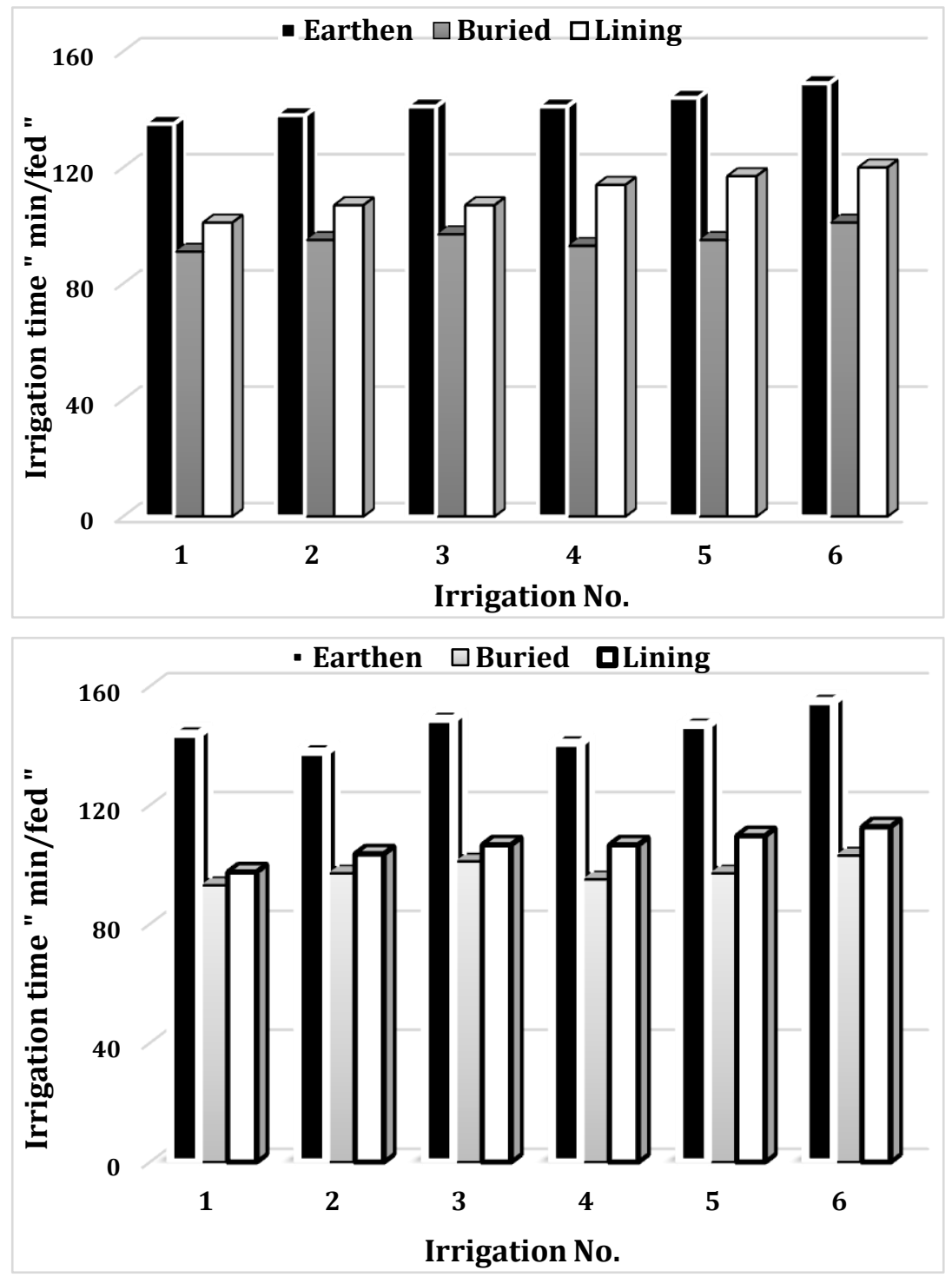

Fig (8): Effect of developed and traditional surface irrigation on irrigation time saving in winter season and summer season.

\subsection{Productivity of crop.}

The grain yields (kg/fed) for wheat and maize crops obtained for the developed and traditional surface irrigation were shown in Table (4). 
The productivity of crops was affected by using developed surface irrigation as it is high compared with traditional surface irrigation. The productivity of maize was $2380 \mathrm{~kg} /$ fed under buried pipes and it was $1960 \mathrm{~kg} \mathrm{/} \mathrm{fed} \mathrm{under} \mathrm{traditional} \mathrm{surface} \mathrm{irrigation.} \mathrm{In} \mathrm{wheat} \mathrm{the}$ productivity was $2850 \mathrm{~kg}$ / fed under developed surface irrigation and it was $2400 \mathrm{~kg} /$ fed under traditional surface irrigation. The lowest value of wheat and maize was under traditional surface irrigation condition. The percentage of increase in productivity of wheat and maize under buried pipes was $18.75 \%$ and $21.43 \%$ respectively compared with traditional surface irrigation. Also, The productivity of maize was $2170 \mathrm{~kg} / \mathrm{fed}$ under lining Mesqa and it was $1960 \mathrm{~kg} /$ fed under traditional surface irrigation. In wheat the productivity was $2625 \mathrm{~kg} / \mathrm{fed}$ under developed surface irrigation and it was $2400 \mathrm{~kg} /$ fed under traditional surface irrigation. The lowest value of wheat and maize was under traditional surface irrigation condition. The percentage of increase in productivity of wheat and maize under lining Mesqa was $9.38 \%$ and $10.71 \%$ respectively.

Table (4). Effect of developed surface irrigation on productivity of crop.

\begin{tabular}{|l|l|r|r|}
\hline \multicolumn{2}{|c|}{ Types of Mesqas } & \multicolumn{2}{c|}{$\begin{array}{c}\text { Productivity } \\
\text { ( kg/fed ) }\end{array}$} \\
\cline { 3 - 4 } \multicolumn{2}{|c|}{} & Wheat & Maize \\
\hline \multirow{2}{*}{ Developed } & Buried pipes. & 2850 & 2380 \\
\cline { 2 - 4 } & Lining Mesqa. & 2625 & 2170 \\
\hline Traditional & Earthen Mesqa. & 2400 & 1960 \\
\hline
\end{tabular}

\subsection{Effect of improved surface irrigation on field water use efficiency.}

Field water use efficiency (FWUE) considered as an indicator of the capability of irrigation system to converting irrigation water to crop. The (FWUE) was considered a tool for maximizing crop production per each unit of water applied. So, values of (FWUE) for wheat and maize were calculated under developed and traditional surface irrigation. Table (5) illustrates the effects of developed and traditional surface irrigation on wheat and maize field water use efficiency. It was found that the value of (FWUE) in buried pipes was $3.23 \mathrm{~kg} / \mathrm{m}^{3}$ for wheat and it was $1.49 \mathrm{~kg}$ $/ \mathrm{m}^{3}$ under traditional surface irrigation. The value of (FWUE) for maize 
under buried pipes was $2.65 \mathrm{~kg} / \mathrm{m}^{3}$ and it was $1.21 \mathrm{~kg} / \mathrm{m}^{3}$ under traditional surface irrigation. Also, found that the value of (FWUE) in lining Mesqa was $1.72 \mathrm{~kg} / \mathrm{m}^{3}$ for wheat and it was $1.38 \mathrm{~kg} / \mathrm{m}^{3}$ under traditional surface irrigation.

From previous results the (FWUE) under developed surface irrigation is higher than that under traditional surface irrigation because of the volume of water applied per feddan in developed surface irrigation less than the traditional surface irrigation and productivity per feddan in developed surface irrigation higher than the traditional surface irrigation so, the (FWUE) under developed surface irrigation is higher than traditional surface irrigation.

Table (5) Effect of developed surface irrigation on (FWUE) for wheat and maize crops

\begin{tabular}{|c|c|c|c|c|c|}
\hline \multicolumn{2}{|c|}{ Type of Mesqas } & $\begin{array}{l}\text { Type } \\
\text { of crop }\end{array}$ & $\begin{array}{c}\text { Yied } \\
\mathrm{kg} / \mathrm{fed}\end{array}$ & $\begin{array}{l}\text { Water } \\
\text { Applied } \\
\text { In season } \\
\left(\mathrm{m}^{3} / \mathrm{fed}\right)\end{array}$ & $\begin{array}{l}\text { WUE } \\
\left(\mathrm{kg} / \mathrm{m}^{3}\right)\end{array}$ \\
\hline \multirow{2}{*}{ Developed } & Buried pipes & \multirow{3}{*}{ Wheat } & 2850 & 881.49 & 3.23 \\
\hline & Lining Mesqa & & 2625 & 1527.04 & 1.72 \\
\hline Traditional & Earthen Mesqa & & 2400 & 1615.34 & 1.49 \\
\hline \multirow{2}{*}{ Developed } & Buried pipes & \multirow{3}{*}{ maize } & 2380 & 899.59 & 2.65 \\
\hline & Lining Mesqa & & 2170 & 1577.18 & 1.38 \\
\hline Traditional & Earthen Mesqa & & 1960 & 1622.25 & 1.21 \\
\hline
\end{tabular}

\section{CONCLUSIONS}

Field experimental works were conducted along two successive seasons of winter 2015/2016 and summer 2016 in Upper Egypt at Assuit governorate, El-Fath city at Arab El-Atawlah branch canal in (OFIDO) national project. The study was conducted to evaluate the improved surface irrigation system and their effects on field water use efficiency 
and yield as the base for integrated surface irrigation management in the old lands.

\section{Where application of (OFIDO) national project leads to the following:}

- Equitable distribution of irrigation water for all farms on (Mesqa).

- Uses the buried pipes instead of Traditional mesq's and maraw's led to increased agricultural area with a rate of $2.3 \%$ and with a rate of $1.5 \%$ in lining canal.

- Raise The conveyance efficiency from $81.41 \%$ in earthen Mesqa to $92.52 \%$ in lining Mesqa and $98.61 \%$ in buried pipes.

- Raise The application efficiency from $58.82 \%$ in earthen Mesqa to $79.07 \%$ in lining Mesqa and $82.09 \%$ in buried pipes.

- Decreasing irrigation time from 143.5 minute per feddan in earthen Mesqa to 113.5 minute in lining Mesqa and 96.5 minute in buried pipes.

- Increasing productivity of wheat and maize under buried pipe was 18.75 and $21.4 \%$ respectively.and $9.38 \%$ and $10.7 \%$ wheat and maize was $12.12 \%$ and $11.6 \%$ respectively under lining Mesqa. Thereby, increasing farmers' income.

- Increasing water use efficiency (FWUE) for wheat were $3.23 \mathrm{~kg} / \mathrm{m}^{3}$, $1.72 \mathrm{~kg} / \mathrm{m}^{3}$ and $1.49 \mathrm{~kg} / \mathrm{m}^{3}$ under buried pipe, lining Mesqa and traditional surface irrigation respectively. Also, field water use efficiency (FWUE) for maize were $2.65 \mathrm{~kg} / \mathrm{m}^{3}, 1.38 \mathrm{~kg} / \mathrm{m}^{3}$ and $1.21 \mathrm{~kg} / \mathrm{m}^{3}$ under buried pipe, lining Mesqa and traditional surface irrigation respectively.

\section{REFERENCES.}

Abd El-Motaleb, I. A. M. A. El-Saadawy F. I. Hindy M.A. Mattar, (2006) Hydraulic analysis of telescopic perforated pipe for surface irrigation. The 14th. Annual Conf. of the Misr Soc. of Ag. Eng., 22 Nov., (2006), p.: 1065-1086 
Black, G. R. and K. Hartage (1986). Bulk density Methods of Soil Analysis.Part1 Agron. 2nd ed. 363376. ASA and SSSA, Madison.

El-Gendy, A. M. (2011). Sustainable use of agricultural resources program. Program board meeting, USA, June.

FAO (Food and agricultural Organization), (1989). Guidelines for Designing and Evaluating Surface Irrigation System: Irrigation and Drainage Paper. No. 45.FAO, Rome.

Hassan, S. S. (1998). Engineering studies for increasing water distribution uniformity of perforated pipes for surface irrigation system. Ph.D., Agric. Eng. Dept., Fac. of Agric., Cairo Univ., Egypt.

Howell, A. T. (2003). Irrigation efficiency. United States Dept. of Agric. (USDA), Bushland, Taxas, U.S.A. Marcel Dekker, Inc. New York.

IFAD International Fund for Agricultural Development $\}$ (2012) The International Fund for Agricultural Development The Arab Republic of Egypt On-farm Irrigation Development Project in the Old lands (OFIDO) Project Design Report Main report, Egypt.

Jibin, Li. and N. Foroud, (1997). Evaluation of a gated pipe basin irrigation method in china. CIDA under China Dryland Project.

Liven, P.C. and Van F.C. Rooyen, (1979). The effect of discharge rate and intermittent water application by point-source irrigation on the soil moisture distribution pattern.Soil Sci.Amer. J. 43: 8-5.

Mostafa Z. B., Kavei D. R., Saghaian N. S. H. and Jalalian A. (2010). The comparison of erosion of meandering and standard furrow irrigation under different field slopes. AJAE 1(2). P.:29-37.

Phocaides A. (2007) Handbook on pressurized irrigation techniques. FAO Consultant, Second Edition. Food and Agric. Organization of the United Nations. Vialedelle 
USDA, NRCS (2012). National Engineering Handbook Part 623 Irrigation chapter 4 Surface Irrigation (623-VI-NEH, September (2012). USDA online at www.ascr.usda.gov.

Walker, W. R. (1989). Guidelines for designing and evaluating surface irrigation systems. Irrigation and Drainage paper 45, FAO, Rome, Italy.

\section{الملخص العربى}

\section{أداء نظام الري السطحي المطور بأسيوط}

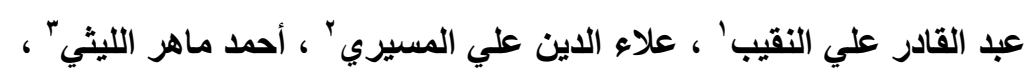

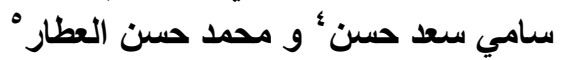

تم اجر اء هذة الدراسة بمنطقة عرب الأطاولة مركز القتح بمحافظة أسيوط، وذلك بهدف تقييم

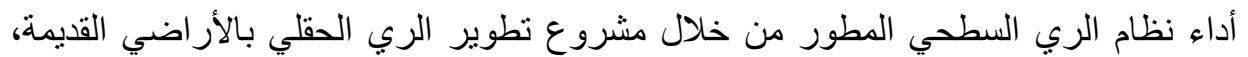

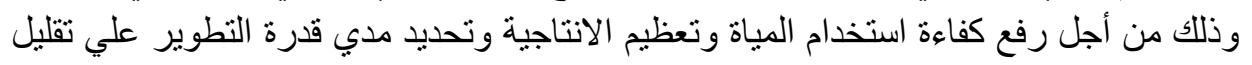

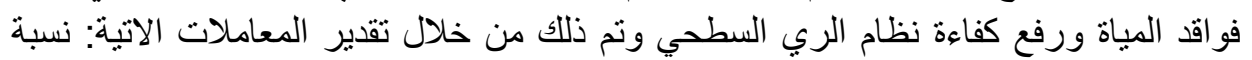

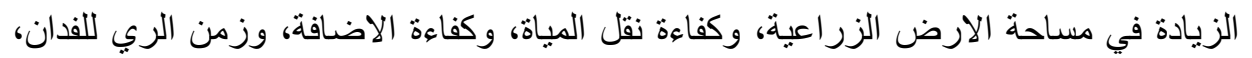

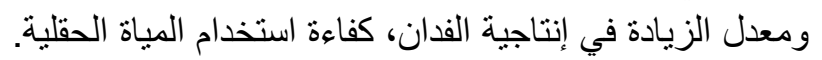

$$
\text { ومن أهم النتائج التي تم الحصول عليها : }
$$

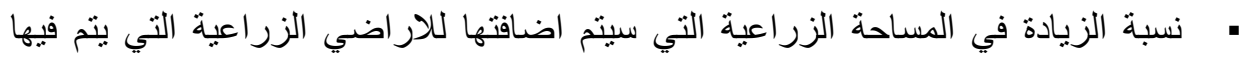

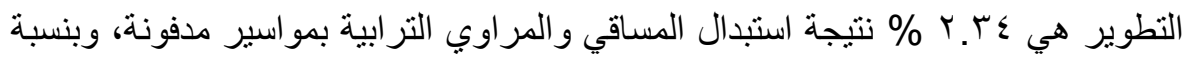

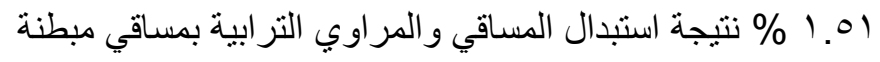

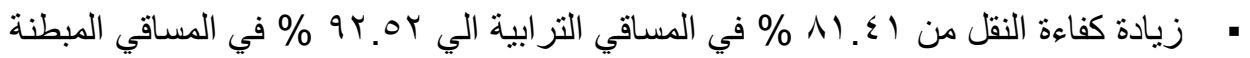

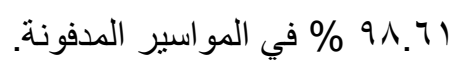

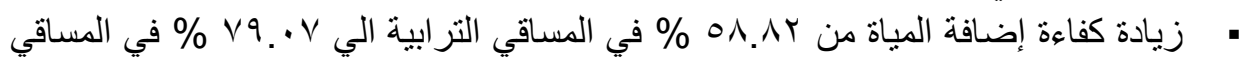

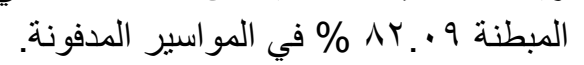

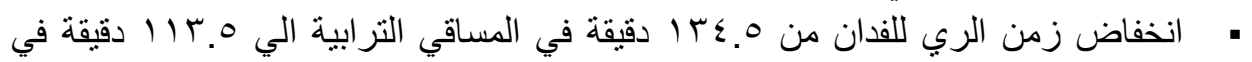

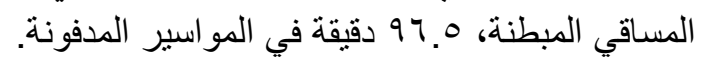

' أستاذ الهندسة الزراعية المتفرغ - كلية الهندسة الزراعية - جامعة الأزهر بالقاهرة.

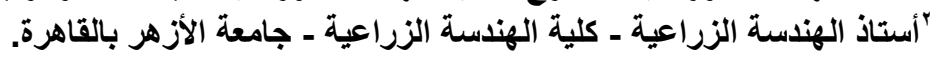

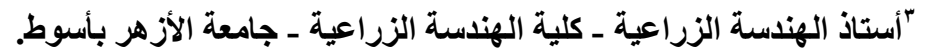

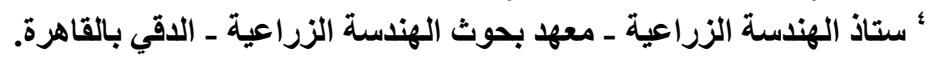
•معيد بالهندسة الزراعية ـ كلية الهندسة الزراعية - جامعة الأزهر بأسيوط. 


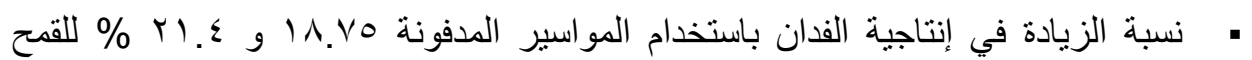

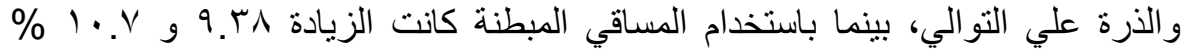
للقمح و الذرة علي التو الي، مقارنة بالمساقي الترابية.

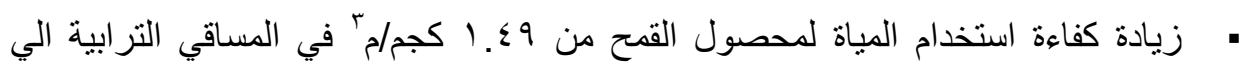

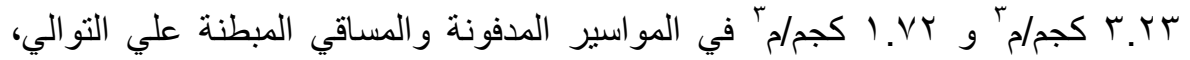

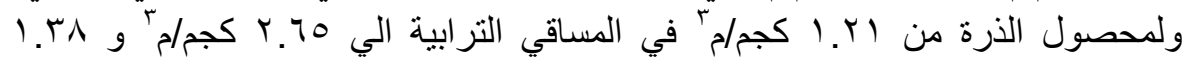

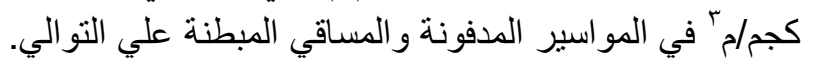

